\title{
Prostaglandin と腎機能
}

\author{
第 3 報 Prostaglandin $A_{2}$ と尿中溶質排泄
}

$\begin{array}{ccccc}\text { 千葉大学医学部泌尿器科学教室 } & \text { 三 } & \text { 橋 } & \text { 慎 } & \text { 一 } \\ \text { (主任 : 百瀬剛一教授 } & \text { 伊 } & \text { 藤 } & \text { 晴 夫 }\end{array}$

PROSTAGLANDIN AND RENAL FUNCTION

(III) The Effect of $\mathrm{PGA}_{2}$, on the Urinary Solutes Excretion

Shinichi Mitsuhashi \& Haruo Ito

Department of Urology, School of Medicine, Chiba University, in Chiba. Japan

(Director: Prof. G. Momose)

1) Twenty-nine cases without upper urinary tract dilatation and renal impairment were studied on urinary solutes excretion induced by $\mathrm{PGA}_{2}$.

2) An intravenous infusion of $\mathrm{PGA}_{2}$ with the rate of $400 \mathrm{ng} / \mathrm{Kg} / \mathrm{min}$. caused marked increases of urine volume and urinary excretion of both sodium and chloride. Especially as for sodium excretion, more increase was observed among hypertensives than normotensives.

3) The same effect of $\mathrm{PGA}_{2}$ was observed at the state of dehydration followed by an intramuscular injection of 5 units of vasopressin. $\mathrm{U}_{\text {osm }}$ decreased slightly, while $\mathrm{C}_{\text {osm }}$ and $\mathrm{T}_{\mathrm{H}_{2} \mathrm{O}}^{\mathrm{C}}$ increased.

4) These effects of $\mathrm{PGA}_{2}$ on urinary solute excretion were supposed to be due to the fact that $\mathrm{PGA}_{2}$ increases the renomedullary blood flow and inhibits the sodium reabsorption at the proximal tubuli.

はじめに

Prostaglandin（以下PG と略す）が多様な作用を有し， しかも特異な構造を有することはよく知られる。ことに $\mathrm{A}$ 群および $\mathrm{E}$ 群は，循環系に対し，強力な効果を有する ことが判明してくるにつれ，その臨床への応用もやがて は一般的なものとなろう．われわれは $\mathrm{PGA}_{2}$ による腎 機能充進作用として，PSP 15分排泄值におよぼす影響 $を^{122)}$ ，また $\mathrm{PGE}_{1}$ による腎血行増強作用として選択的 腎動脈撮影像におよぼす影響を報告しだ)。

今回は, $\mathrm{PGA}_{2}$ 投与時の腎機能に対する作用として, $2 \sim 3$ 物質の尿中への排泄に扣よぼす効果を検討したの で，以下ここにその概略を述べたいと思う.

\section{方 法}

当科入院症例中，腎機能良好でから上部尿路に抾張の ない成人 29 例を選んだ. 年令は 19〜78才で，男女比は 男 18 : 女11例である. 対象は 2 群に分け, 第 1 群の 20 例 は, 食後 $1 \sim 2$ 時間は避けたものの, 特に水分環境に条
件はつけず，尿道に留置カテーテルを置き，30分毎に 4 回の分画で採尿した．この間, 前腕正中静脈より生理的 食塩水 (以下生食水と略す) $0.16 \mathrm{ml} /$ 分の 定速で持続 注入ポンプを用いて投与,その第 2 分画,すなわち投与開 始30分以降60分までの間は, 生食水にて溶解した $\mathrm{PGA}_{2}$ を $400 \mathrm{ng} / \mathrm{kg} /$ 分投与に切り换えた. 毎分投与液量は不変 である. かくして各分画尿（以下 $\mathrm{U}_{1 \sim 4}$ と略す）につい て, 尿量, 尿中 Urea $\mathrm{N}$, Creatinine, $\mathrm{Na}, \mathrm{K}$, および Cl 量を測定した. また,この全経過中, 経時的に血圧測定 を行なつた．この第 1 群を以下 PG 群と略す.

第 2 群としては 9 症例について, 完全濃縮条件として Fischberg 濃縮試験と同様の前隼備，すなわち，前日 6 PM 以降の飲食を禁し，当日は $7 \mathrm{AM}$ より留置カテーテ ルにより，15分毎の分画で採尿した. この間, PG 群 と同じく生食水の少量持続投与をなし， $\mathrm{U}_{2}$ 採取直後 Vasopressin succinate（以下 ADH と略す） 5 単位の筋注 を加兄， $\mathrm{U}_{4}$ 採取直後には生食水を $\mathrm{PGA}_{2}$ の同一量に切り 
換兄， $\mathrm{U}_{6}$ 終了時再び生食水にもどした。 また，この群 (以下 $\mathrm{ADH}$ 併用群と略す) では, $\mathrm{U}_{2}, \mathrm{U}_{4}, \mathrm{U}_{6}, \mathrm{U}_{8}$ の各 分画の中間点で採血した. 血液は血浆を分離, 尿と共に PG 群と同様の測定をなし，かつこの群では浸透压を Fiske の Osmometer により測定した. 血圧の計時的測 定もPG 群と同様に行なつた.

\section{成 績}

前述の如く, PG 群と ADH 併用群とに分けて示す. a) PG 群

$\mathrm{PGA}_{2}$ 投与直後より，ほぼ全例に血圧の多少の低下， 心拍数の軽度の上昇が見られたが, 自覚的には著変は全 く見られなからた. から, 投与数分後より明らかに尿量 の増加が見られ, この尿量増は $\mathrm{U}_{2}$ 分画にのみ特異的で あり, $\mathrm{U}_{3}$ 分画では殆ど前值に近く, $\mathrm{U}_{4}$ ではもはや PG の残効は見られなかつた. 今すべての測定值を $\mathrm{U}_{1}$ に対 する比として算出して図に示すと，第 1 四の如くにな る. すなわち各分画に拊ける排泄総量比で見ると, 尿量 および $\mathrm{Na}$ と $\mathrm{Cl}$ に执いて， $\mathrm{PGA}_{2}$ による增加が著し い.また，濃度として見ると，殆ど動きは少なくなり，

図 1 P G 群尿中溶質排泄量比
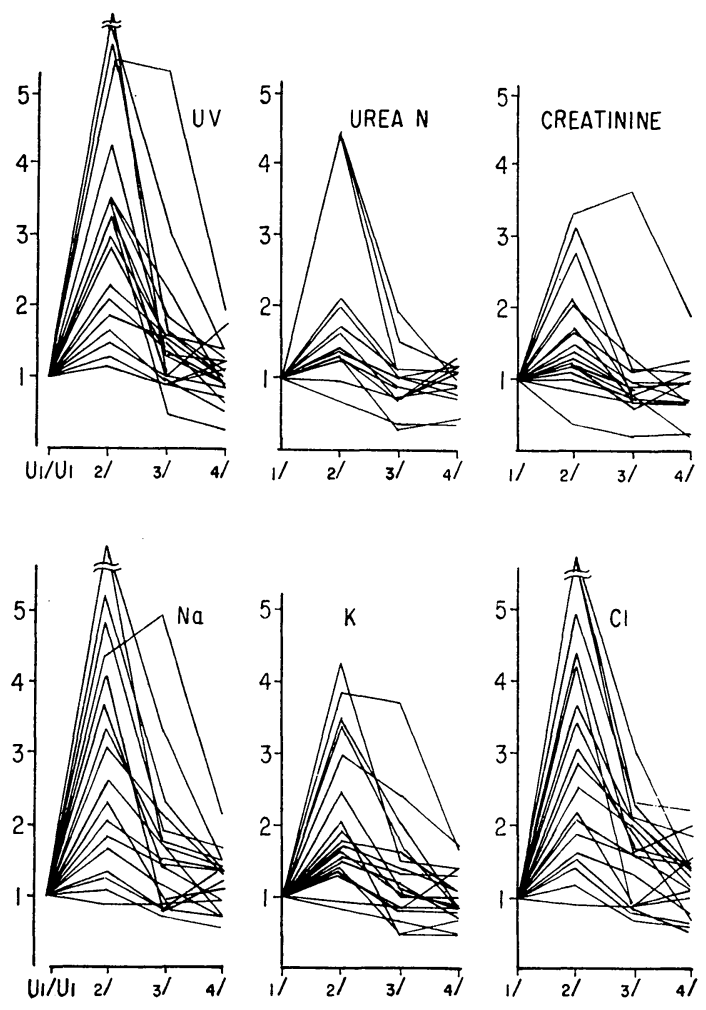

図 $2 \quad \mathrm{P} \mathrm{G}$ 群尿中溶質濃度比
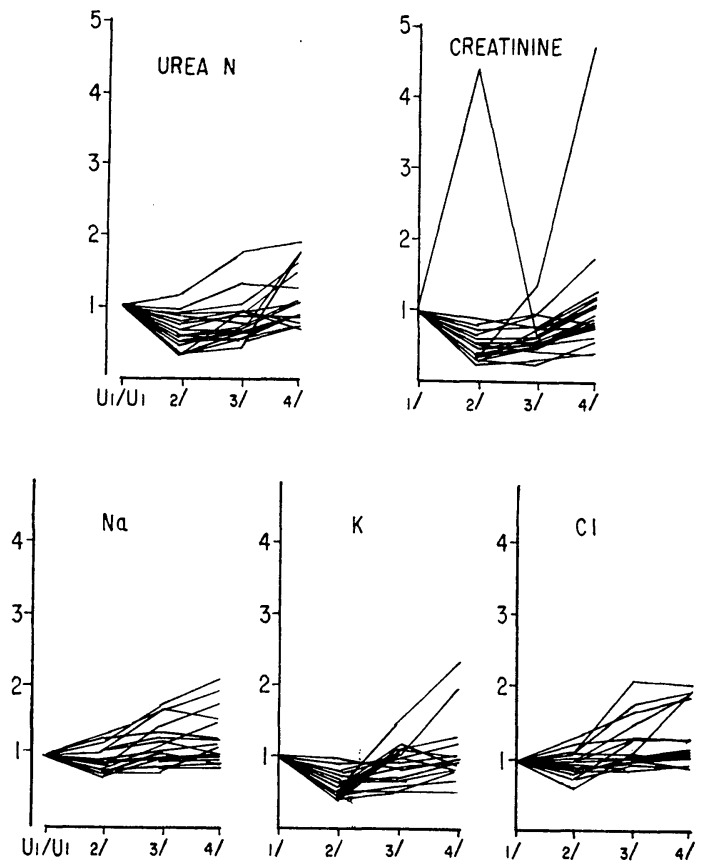

表 1 P G 群尿中溶質排泄量比

\begin{tabular}{|c|c|c|c|}
\hline & $\begin{array}{ll}\text { 尿 } & \text { 中 } \\
\text { 濃 度 比 }\end{array}$ & $\begin{array}{l}\text { 厡 中 } \\
\text { 排泄量比 } \\
\end{array}$ & $\begin{array}{c}\text { ネフロン当り } \\
\text { 排泄量比 }\end{array}$ \\
\hline $\mathrm{UV}$ & & $3.90 \pm 0.36$ & $8.01 \pm 0.12$ \\
\hline Urea $\mathrm{N}$ & $0.69 \pm 0.05$ & $1.70 \pm 0.18$ & $1.35 \pm 0.09$ \\
\hline Creatinine & $0.71 \pm 0.07$ & $1.59 \pm 0.03$ & \\
\hline $\mathrm{Na}$ & $0.94 \pm 0.04$ & $3.05 \pm 0.03$ & $2.18 \pm 0.23$ \\
\hline $\mathrm{K}$ & $0.69 \pm 0.03$ & $2.04 \pm 0.14$ & $1.46 \pm 0.10$ \\
\hline $\mathrm{Cl}$ & $0.95 \pm 0.02$ & $2.97 \pm 0.20$ & $2.16 \pm 0.27$ \\
\hline
\end{tabular}

（平均士標準誤差）

一般にはむしろ尿量の増加により，むしろ稀釈されてい ることがらかがわれた（第 2 図）。

これを $\mathrm{U}_{1}$ に対する比の数値として表示すると表 1 の 如くになる. すなわち, 濃度の上からは, Urea N, Creatinine, $\mathrm{K}$ などは明らかに大きく稀释を受け，また $\mathrm{Na}$ と $\mathrm{Cl}$ についても多少の稀釈は見られ，一方排泄量から 見れば，水分, $\mathrm{Na}$ および $\mathrm{Cl}$ の積極的な排泄量増加が 明らかであつた. ちなみに単位ネフロン当りの数值とし て, 各排泄量比を Creatinine クリアランスを以て除し て見ると, 表の最右䦥に示す数值となつた.

また, これら20例を血圧の値により, 高血圧, 正常血 匠の 2 群に分けて検討して見た.すなわら最高血圧 150 
表 $2 \quad \mathrm{P} \mathrm{G}$ 群, 血圧による尿中排泄量比の差

\begin{tabular}{l|c|c}
\hline & 正常血圧群 & 高 血压群 \\
\hline $\mathrm{U} \mathrm{V}$ & $2.72 \pm 0.47$ & $3.90 \pm 0.45$ \\
\hline Urea N & $1.66 \pm 0.29$ & $1.98 \pm 0.21$ \\
\hline Creatinine & $1.39 \pm 0.16$ & $1.81 \pm 0.27$ \\
\hline $\mathrm{Na}$ & $2.35 \pm 0.42$ & $3.84 \pm 0.50$ \\
\hline $\mathrm{K}$ & $1.88 \pm 0.10$ & $2.23 \pm 0.28$ \\
\hline $\mathrm{Cl}$ & $2.60 \pm 0.47$ & $3.39 \pm 0.60$ \\
\hline
\end{tabular}

(平均土標準誤差)

表 $3 \mathrm{~A} \mathrm{D} \mathrm{H}$ 併用群の水分出納

\begin{tabular}{l|c|c|c}
\hline & $\mathrm{U}_{4}$ & $\mathrm{U}_{5}$ & $\mathrm{U}_{6}$ \\
\hline $\begin{array}{l}\text { Uosm } \\
\left(\mathrm{mOsm} / \mathrm{kg} \cdot \mathrm{H}_{2} \mathrm{O}\right)\end{array}$ & $816 \pm 29$ & $742 \pm 31$ & $719 \pm 44$ \\
\hline $\mathrm{UV}(\mathrm{ml} / \mathrm{min})$ & $0.62 \pm 0.26$ & $0.96 \pm 0.30$ & $1.11 \pm 0.20$ \\
\hline $\begin{array}{l}\text { Posm } \\
\left(\mathrm{mOsm} / \mathrm{kg} \cdot \mathrm{H}_{2} \mathrm{O}\right)\end{array}$ & $291 \pm 5$ & & $288 \pm 5$ \\
\hline $\operatorname{Cosm}(\mathrm{ml} / \mathrm{min})$ & $1.74 \pm 0.64$ & $2.47 \pm 0.40$ & $2.77 \pm 0.21$ \\
\hline $\mathrm{T}_{\mathrm{H}_{2} \mathrm{o}}^{\mathrm{C}}(\mathrm{ml} / \mathrm{min})$ & $1.12 \pm 0.14$ & $1.51 \pm 0.07$ & $1.66 \pm 0.11$ \\
\hline
\end{tabular}

$\left(\mathrm{U}_{4} \sim \mathrm{U}_{6}:\right.$ 本文参照 $)$

（平均土標準誤差）

$\mathrm{mgHg}$ ，最低血圧 $90 \mathrm{~mm} H \mathrm{H}$ のいづれかでもこえているすの 9 例と，双方ともそれ以下のもの11例について， $\mathrm{U}_{2} / \mathrm{U}_{1}$ の 比を以て検討した. その結果は表 2 に見る如く, すべて の值に执いて高血圧例の方が大であり，ことに $\mathrm{Na}$ 排 泄量比で明らかであつた。

\section{b ) $\mathrm{ADH}$ 併用群}

この群では $\mathrm{ADH}$ 筋注により, 多少の血圧上昇を示 し，かつ少数例に沶いては軽い心情穴進を訴えたが，そ れ以外にはさして変化がなかつた。 また，これに更に $\mathrm{PGA}_{2}$ 静脈内持続投与を行ならと，血圧は前値にもどる か，またはむしろやや低下の傾向が見られた。 かつ PG 群と同様に，尿量の増加が数分以内に起つたが， $\mathrm{U}_{1} \sim$ U. の PG を加える前の各分画に和いては，尿の浸透圧 は注ぼ一定であり，生体は充分な濃縮条件にあつたこと は確実であつた: $U_{4}\left(A D H\right.$ 投与後の 第 2 分画)， $U_{5} \sim$ $\mathrm{U}_{6}\left(\mathrm{PGA}_{2}\right.$ 投与中の分画) の間の尿量，尿浸透圧などの 実測値を表 3 に示す。すなわち 尿漫透圧（Uosm と略 す）は鿰減，尿量（表中 UV）は逆に增加，血浆浸透 圧（Posm と略す）はほぼ一定, 浸透圧クリアランス (Cosm と略す) は増加し，そして水分再吸収量 ( $\mathrm{T}_{\mathrm{H}_{2}}^{\mathrm{C}} \mathrm{O}$ と略す）も增加していた．以下 PG 群と同様に，尿中排 泄量について $\mathrm{U}_{4}$ に対する増減比として四示すると四 3
図 3 A D H併用群の $\mathrm{PGA}_{2}$ 投与による 溶質排泄量比
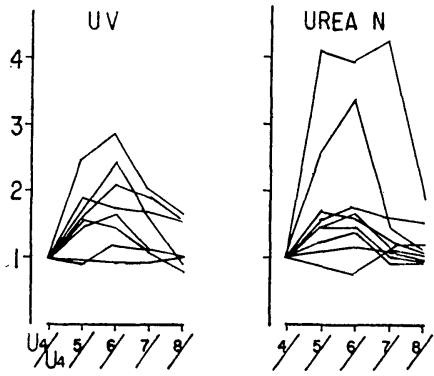

CREATININE
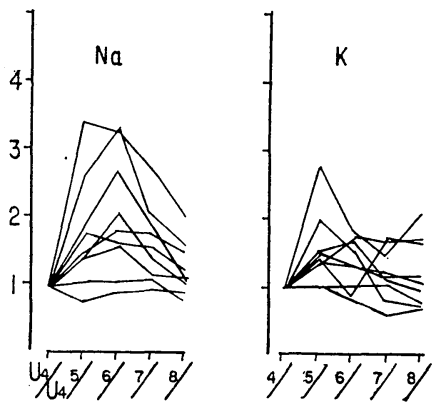

$\mathrm{Cl}$
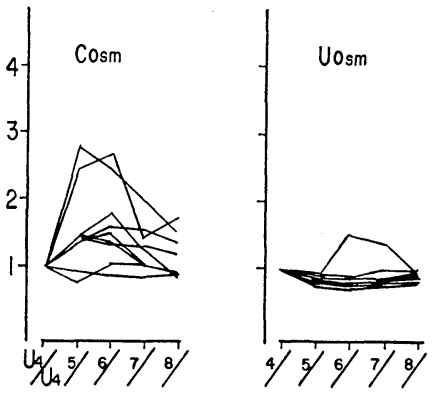

$\mathrm{T}_{\mathrm{H}_{2} \mathrm{O}}^{\mathrm{C}}$
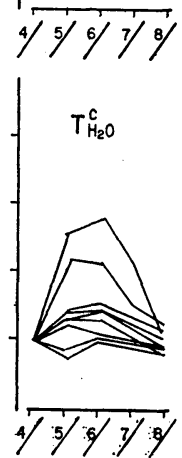

表 4 A D H併用群の $\mathrm{PGA}_{2}$ 投与による 溶質排泄量比

\begin{tabular}{l|c|c}
\hline & $\mathrm{U}_{5} / \mathrm{U}_{4}$ & $\mathrm{U}_{6} / \mathrm{U}_{4}$ \\
\hline Urea & $1.66 \pm 0.23$ & $1.77 \pm 0.27$ \\
\hline Creatinine & $1.32 \pm 0.13$ & $1.09 \pm 0.06$ \\
\hline $\mathrm{Na}$ & $1.78 \pm 0.28$ & $2.06 \pm 0.30$ \\
\hline $\mathrm{K}$ & $1.59 \pm 0.18$ & $1.39 \pm 0.13$ \\
\hline $\mathrm{Cl}$ & $1.56 \pm 0.13$ & $1.67 \pm 0.20$ \\
\hline $\mathrm{U} \mathrm{V}$ & $1.55 \pm 0.16$ & $1.85 \pm 0.24$ \\
\hline Uosm & $0.91 \pm 0.08$ & $0.88 \pm 0.04$ \\
\hline Cosm & $1.60 \pm 0.23$ & $1.68 \pm 0.19$ \\
\hline $\mathrm{T}_{\mathrm{H}_{2} \mathrm{O}}^{\mathrm{C}}$ & $1.51 \pm 0.21$ & $1.54 \pm 0.19$ \\
\hline
\end{tabular}

$\left(\mathrm{U}_{4} \sim \mathrm{U}_{6}\right.$ : 本文参照 $)$

（平均士標準俱差） 


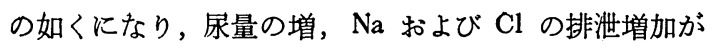
目立つが，これに対しUrea N は一部に著しい排泄增の 見られたものがあるが，全体としては Creatinine と同 じくさしたる変化はないよらであつた. Uosm の比はほ ぼ全例で多少の低下，そして Cosm はやや区々ではあ るが増加が認められた。

これらの变化をPG 群と同様に数值で示すと, 表 4 の 如く， $\mathrm{U}_{6} / \mathrm{U}_{4}$ の欗で明らかなように，尿量拉よび $\mathrm{Na} の$ 增加が顕著であつた。

\section{考按}

PG の中で，A群およびE 群が血管扗張性物質であ り,ことにA群は肺循環により不活性化されないため， 末梢静脈に投与してもその作用を発現することが知られ ている.この血管执張作用は身体随所に見られるが，腎 もとの標的器官として好適であり, 近年多くの報告が見 られるようになつた. この腎内血管の拡張は，われわれ も腎 Microangiographyにより形態的に証明し，一部は 学会において報告しだ).

かくの如き血管拡張は，当然に腎血流の增加を招き， これがため腎尿細管レベルでの溶質の移動に大きな影響 を与えることになる.われわれのこの度の臨床的な検索 では, $\mathrm{PGA}_{2}$ の微量の全身投与により, 著しい利尿効果 を来すことを見たが，これは主として $\mathrm{Na}$ (および $\mathrm{Cl}$ ) の排泄增加が与かつていることを認めた。 このような利 尿効果を招来する 因子の一つとして 血圧の如何, およ び系球体濾過量の如何が大きく関与し得るが，少なくと も今回の投与量では, 血圧にはさほどの変化はなく, せ いぜい最高血圧および最低血圧共に $10 \mathrm{~mm}$ 程度の, しか も下降であつて, この意味からすれば, 尿量增加とは無 関係であり，またかかる小さな変化ではこれによる糸球 体濾過量も変化はないと推定される. 事実, われわれが 後日報告する如く, $\mathrm{PGA}_{2}$ のこの量では系球体濾過量に はさしたる変化がないことが証明されている．従つてこ の尿量增加は上記 2 つ因子以外によると推定され, 結 局腎血流の増加, ことに腎㭪啠血流の増加が強く予想さ れよう.これについてるわれわれはこのことを推定出来 る実験成績を得ているが，ここでは省略する.

PG のA 扣よび $\mathrm{E}$ 群は，ともに血管払張作用を認める 他, 心拍出量も增加させることが知られているが, 尿管 の運動性に対してはAは影響なく，Eはむしろ抑制的で あるとされ，またその他にも E 群は胃腸など消化管の運 動性を亢進させるなど，かなり異つた作用も知られてい る. しかし，腎に対する作用には類似点も多く，Her- $\operatorname{zog}^{5) 6)}$ らの報告ではイ 又の腎動脈内に $\mathrm{E}_{1}, \mathrm{E}_{2}$, および $\mathrm{A}_{1}$ を用いた時には，同側の尿量，腎血流量および自由水ク リアランス (以下 $\mathrm{CH}_{2} \mathrm{O}$ と略す) の増が見られ，から この $\mathrm{CH}_{2} \mathrm{O}$ の増は上述 3 者間に差がないという，またこ の際, 外因性の $\mathrm{ADH}$ により, $\mathrm{PGA}_{1}$ のこの作用は抑制 されなかつたとしているが，ADH の量については判然 としない。また Vander ${ }^{7)}$ は同じくイヌを用いて抗利尿 状態下で $\mathrm{PGE}_{1}$ または $\mathrm{E}_{2}$ を腎動脈内に注入した折の 尿量と Na 排泄の增は腎血流量の変化とは無関係に見ら れるという. 今回の対象からは除外したが, 著しい高窒 素血症を有する末期腎不全例に护ける観察では， $\mathrm{Na} の$ 排泄増加は殆ど見られなかつたことから見て，やはりあ る程度の腎血流量が保たれていることが， Na 利尿の必 要条件であろう.

この Na の排泄量の増加は, 系球体濾過量が殆ど变ら ないとすれば，結局尿細管における $\mathrm{Na}$ の再吸収の抑制 が原因となる. 上記の如く, 腎内循環の増加が起これ ば，尿細管細胞との間の溶質の授受は抑制され，従つて 糸球体滤液よりの $\mathrm{Na}$ ，ひいては水分の再吸収は減少す る. 一般的にはこれが $\mathrm{PGA}_{2}$ 投与時に拈ける利尿効果 の大きな原因であろう． Fülgraff( ${ }^{8)}$ は $\mathrm{PGE}_{2}$ の投与に よる $\mathrm{Na}$ 排泄の増をラットを用いて検討, $1 \mu \mathrm{g} / \mathrm{kg} /$ 分の 量では尿量よりむしろ $\mathrm{Na}$ の排泄増が著しく，かつK排

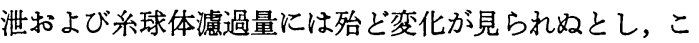
の $\mathrm{Na}$ 利尿は尿細管に怙ける $\mathrm{Na}$ の再吸収抑制によると い, 同様に $\mathrm{PGA}_{1}$ について Lee ${ }^{9)}$ \& $\mathrm{Na}$ 再吸収減を 主因と見ている. 更に彼 ${ }^{10}$ はこの $\mathrm{Na}$ に関し, 濾過 $\mathrm{Na}$ 量が不変であつても単位ネフロン当りの $\mathrm{Na}$ 排泄量の増 を証明している。われわれの成績でも， Na 排泄の絶対 量の著増は, この間における系球体濾過量の著変がな いとすれば, 当然単位ネフロン当りの $\mathrm{Na}$ 排泄增を意味 し，このことは，とりもなおさず尿細管に就けるその再 吸収の減に帰結すると考兄られる. かかる Na の排泄の 增加が, 表 2 に示した如く, 高血圧例において, 上り著 明に見られたことは甚だ暗示的である. 表中の諸数值の すべてにおいて，高血圧例の方が排泄量が大であつた が，この中で有意差のあるのは $\mathrm{Na}$ である. 遠山ら ${ }^{11}$ は $\mathrm{PGA}_{2}$ を微量からやや大量にまで投与量を漸增しつつ正 常血圧例と, 本態性高血压例について反応を検討, 前者 では $\mathrm{PGA}_{2}$ の量の如何によらず $\mathrm{Na}$ 利尿を認めなかつ たが, 後者では著しいNa 排泄增加を証明したとしてい る. しかし，われわれの検討では，正常血圧例でも $\mathrm{Na}$ の排泄増加は明らかであつた．ただし高血圧例の方が著 
しかつたことは前述の通りで, PG ことに $\mathrm{A}_{2}$ が腎䯣質 中の降圧物質 Medullin として登場した事実, そして一 時は $\mathrm{Na}$ 利尿ホルモンそのものではないかとすら見られ た事実を裏書きするものであろう．PG は腎のレニン分 泌には影響がないとする見解が多いが，しかし高血圧例 に抢いてことに Na 排泄をさせることは，原因は何であ れ，腎血管の挛縮もしくはとれに類似する状態に 対し て，ことに強く作用し，腎血行を改善させることを想わ せる.この PG の作用部位は, 恐らくはV Vas efferns で あると推定される.

また，かかる $\mathrm{Na}$ 利尿作用は， $\mathrm{Na}$ 眝溜性の疾患に 対する治療としても期待される. PGA $\operatorname{man}^{12)}$ の検討では, 高血圧を含む対象の中で, 肝硬变症 に执いてことに Na 排泄の増加が見られたと報告してお。 り, 高血圧以外に 2 次性アルドステロン症に対する使用 も考慮されてよい。

この $\mathrm{Na}$ と密な関係を有するのが $\mathrm{Cl}$ である. 自験成 績では, PG 群でも, また ADH 併用群でも, ほぼ Na と同一の様相を示して増量し，尿量増加の一つの原因と なつていると思われた. しかし Urea N については排 泄量自体は増加しているるのの，むしろ尿量増加による 副次的のものと考兄られ, Creatinine 同様, 積極的な意 義は少ないものであろう.

一方，Kの排泄增は，近位尿細管に怙ける Na の再吸 収抑制の 折に起る附随的な变化であるのか，あるいは PG 投与に上り副腎皮質からのアルドステロンの分泌元 進が萀起されることによるのかは不明であるが，少なく もUrea の排泄増加よりは何らかの積極的な因子を考兄 たい. Lee ら ${ }^{13)}$ む $\mathrm{PGA}_{1}$ の微量投与での尿中Kの排泄 増加を報告しているが，目下のところ，その機序は明ら かでない。

これら溶質の排泄と密接に関連するのが，水分の排出 である. 最も端的には尿量の増加で示されるが，PG 群 では約 4 倍に尿量の増加することが判明したが，今これ を単位ネフロン当りについて見ると, 前揭表 1 の如く, $\mathrm{Na}, \mathrm{Cl}, \mathrm{K}$, Urea $\mathrm{N}$ の各ネフロン当りの排泄量の和に, 更に Creatinine の排泄量（これは1である）を加えた あのを, 尿量の単位ネフロン当りの増加率とはほぼ等し い.すなわち，極めて粗な類推であるが，この尿量の增 は，各溶質の排泄量の増加により導かれた利尿であると 想定されよう.

一方, ADH 併用群においては, 生体は極限の濃縮条 件下にあつたと考穴られ，事実， $\mathrm{U}_{1}, \mathrm{U}_{2}$ と $\mathrm{ADH}$ 投与
後の $\mathrm{U}_{3}$ 㧊よび $\mathrm{U}_{4}$ の尿浸透圧にはさして差がなかつ た.ここで $\mathrm{PGA}_{2}$ を $400 \mathrm{ng} / \mathrm{kg} /$ 分の量を持続投与するこ とにより，著しい濃縮環境下にもかかわらず，生体は 尿量を汇涪増している．またこの際は尿浸透圧の多少 の低下を示していた．少しくこれについて述べるなら， 尿量の増加により，尿の浸透圧は下降するものの，充分 な濃縮条件下にあつて見れば，腎䯣質の間質浸透圧の下 降，もしくは ADH 支配下にある 遠位以下の 尿細管腔 に到達する液量が多くなるためるあつて, $\mathrm{T}_{\mathrm{H}_{2}}^{\mathrm{C}} \mathrm{o}$ 自体の絶 対量は増加している.つまり, 尿量の増加, Uosm の低 下がありながらも $\mathrm{T}_{\mathrm{H}}^{\mathrm{C}} \mathrm{o}$ は増したといら，一見矛盾した 成績は，絶対量から見た場合，尿量の增加よりもむしろ Cosm の増の方が大であつたことを意味している.す なわち Uosm は $816 \rightarrow 719 \mathrm{mOsm} / \mathrm{kg} \cdot \mathrm{H}_{2} \mathrm{O}$ へと $88 \%$ に 減，尿量は $0.62 \rightarrow 1.11 \mathrm{ml} /$ 分へと $79 \%$ の增，そしてPosm は $291 \rightarrow 288 \mathrm{mOsm} / \mathrm{kg} \cdot \mathrm{H}_{2} \mathrm{O}$ 一と僅か $(1 \%)$ の減に留 まって拈り，一般式 UV/P 飞拈いて U/P は多少減少 しながらもVの增により Cosm は大となり，かつ U/P そのあのが大であるため Cosm がVより大となつたこと を示す。これは $\mathrm{PGA}_{2}$ により近位尿細管にお就る $\mathrm{Na}$ の 再吸収阻止により, 集合管への 流入量の增加がひき起 した変化であるう．Fichman ${ }^{14)}$ は $\mathrm{PGA}_{1}$ をとトに用い て, ADH との関係を論じ, ADH 単独に比し $\mathrm{PGA}_{1}$ を 更に加光た場合 $(0.25 \sim 0.5 \mu \mathrm{g} / \mathrm{kg} /$ 分 $)$ 尿量の增加, Cosm の増加と共に, $\mathrm{T}_{\mathrm{H}_{2} \mathrm{O}}^{\mathrm{C}}$ の増の成績を示しており, この点は $A_{1}$ と $A_{2}$ の差はあるものの, 自験成績に一 致している. 更に彼は $\mathrm{A}_{1}$ と $\mathrm{E}_{1}$ とでは異なり， $\mathrm{E}_{1}$ が $\mathrm{ADH}$ 阻止的であるのに対し， $\mathrm{A}_{1}$ は ADH に無関保で

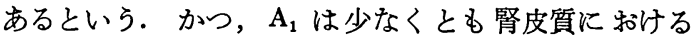
cyclic AMP の賦活作用があり，これが PGA $_{1}$ の利尿 作用の大きな源である可能性を説いている。 一方 ADH もまたその作用には cyclic AMP を介するとされてい るので, この意味では $A_{1}$ と $\mathrm{ADH}$ とはむしろ協調的で すらあることになる. しかし $A_{1}$ と $A_{2}$ とでは当然異な る点があり，一部には $\mathrm{A}_{2}$ の $\mathrm{Na}$ 利尿作用はむしろ腎内 の Na およびKに依存する ATP 酵素を抑制することに よるというすのるある. いら゙れにせよ，ADH 支配環境 下にあつても， $\mathrm{PGA}_{2}$ の投与により，水の再吸収を増し ながらもそれを上迴つて利尿効果が発揮されたわけであ り，もし $\mathrm{ADH}$ 支配下になければ $\mathrm{C}_{2} \mathrm{O}$ の激增の形を 示したことは想像に 難くない。この水分代謝に 対する PG の効果は，生体の条件により異なり Fichman ${ }^{12)} の$ 検討では，尿中 $\mathrm{Na}$ 排泄は，水負荷時に比し， ADH 投 
与時に激増したという。自験成績では, $\mathrm{PGA}_{2}$ 単独投与 では $\mathrm{Na}$ は約 3 倍に, ADH 環境下では 2 倍弱に増加を 示し，上述の報告とはやや異なつているが，これは $\mathrm{ADH}$ 併用群での比較が $\mathrm{ADH}$ 投与時と, それに $\mathrm{PGA}_{2}$ を加 えた時との比で見ている故もあるものの，ADH 投与前 の值とで比較しても, やはり $\mathrm{U}_{6}$ での $\mathrm{Na}$ 排泄量は2.15 倍であり，この Fichman の值とは異なつている. 恐ら く自験対象がすでに $\mathrm{ADH}$ を投与しない折にも，充分な $\mathrm{ADH}$ 優位にあつたためであろう. ちなみに $\mathrm{U}_{1} \sim \mathrm{U}_{2}$ の $\mathrm{Na}$ に対する $\mathrm{U}_{3} \sim \mathrm{U}_{4}$ の $\mathrm{Na}$ は1.12倍と1.03倍で, 殆ど $\mathrm{ADH}$ による $\mathrm{Na}$ 排泄の増は示されていなかつたことか らもらかがわれよう.

また図に示して 数值的に 表示はしなかつたが， $\mathrm{PGA}_{2}$ 投与を中止した後の分画については， $\mathrm{PGA}_{2}$ の効果は極 めて短時間のうちに消失することが判る. 逆にいえば, $\mathrm{PGA}_{2}$ の諸種の作用, 少なくも腎に対する作用の大部分 は, 他のホルモンその他を介するものではなく，かなり 腎に対して直接的なるのであることを想像させよう。

以上の如く, $\mathrm{PGA}_{2}$ が極めて微量でも, 強い $\mathrm{Na}$ 利尿 作用を示すこと，乙かも $\mathrm{ADH}$ 支配環境下でも尿量の増 加を示すことが判明したが，これを臨床上に応用すると なると，まだ各種の险路がある. しかし全く生理的な物 質であり，かつ極めて示唆に富む薬理作用を有すること から見ても，この臨床応用の近いことを望みたい。

\section{結 論}

上部尿路扗張がなく, 総腎機能に著変のない泌尿器科 症例29例飞 $\mathrm{PGA}_{2} 400 \mathrm{ng} / \mathrm{kg} /$ 分の 静脈内持続注入を行な い, 尿中溶質排泄量の変化を追究した. その結果， $\mathrm{PGA}_{2}$ により，尿量の著増が見られ，これは $\mathrm{ADH}$ 支配 下でもほほ同様であり，またこの尿量増加は主として $\mathrm{Na}$ 排泄増によると認められた。この $\mathrm{Na}$ 利尿は高血圧
例に怙いて明らかに著明であつた. かつ, ADH 支配下 でも $\mathrm{PGA}_{2}$ により Cosm の增加と共に $\mathrm{T}_{\mathrm{H}_{2}}^{\mathrm{C}} \mathrm{O}$ の增加が 証明された。

御指導・御校閲下された百瀬教授に深謝する。本論文 の一部は日本泌尿器科学会第61回総会および, 同第 344 回東京地方会において発表した。

1) 伊藤晴夫, 三橋慎一, 百瀨剛一：日泌尿会誌, 65, 44, 1974.

2) Ito, H., Mitsuhashi, S. \& Momose, G.: Prostaglandins, 3, 359, 1973.

3）伊藤晴夫, 三橋慎一：日泌尿 会誌，65，229, 1974.

4) 三橋慎一：日泌尿会誌，64，705，1973.

5) Herzog, J.P., Johnston, H.H. \& Lauler, D.P.: New Engl. J. Med., 278, 219, 1968.

6) Herzog, J.P., Johnston, H.H. \& Lauler, D.P.: Clin. Research, 16, 386, 1968.

7) Vander, A.J.: Am. J. Physiol., 214, 218, 1968.

8) Fülgraff, G. \& Maiforth, A.: Pflügers Arch., 330, 243, 1971.

9) Lee, J., Kannegiesser, H., O'Toole, O.J. \& Westura, E.: Ann. New York Academy Sci., 180, 218, 1971.

10) Lee, S.J., Johnson, J.G., Smith, C.J. \& Hatch, F.E.: Kidney Intern., 1, 254, 1972.

11) 遠山竜彦, 村上健治, 黑田满彦: 最新医学, 27, 2279, 1972.

12) Fichman, M.P.: Clin. Res., 17, 429, 1969.

13) Lee, J.B., McGiff, J.C., Kannegiesser, H., Mudd, J.G., Aykent, Y. \& Frawley, T.F. Clin. Res., 17, 456, 1969.

14) Fichman, M.P., Litenburg, G., Brooher, G. \& Horton, R.: Circ. Res., 31, Suppl. II, 19, 1972.

（1974年 4 月 2 日受付） 